\title{
Knockdown of Ski decreases osteosarcoma cell proliferation and migration by suppressing the PI3K/Akt signaling pathway
}

\author{
XIN ZHAO $^{1 *}$, YUYING FANG ${ }^{2 *}$, XINGWEN WANG ${ }^{3}$, ZHOUYUAN YANG $^{1}$, \\ DONGHAI LI ${ }^{1}$, MENG TIAN ${ }^{4}$ and PENGDE KANG ${ }^{1}$ \\ ${ }^{1}$ Department of Orthopedic Surgery, West China Hospital, Sichuan University, Chengdu, Sichuan 610041; \\ ${ }^{2}$ Weifang Maternal and Child Health Hospital, Weifang, Shandong 261000; \\ ${ }^{3}$ The Second Clinical Medical College of Lanzhou University, Lanzhou, Gansu 730030; \\ ${ }^{4}$ Neurosurgery Research Laboratory, West China Hospital, Sichuan Univerisity, Chengdu, Sichuan 610041, P.R. China
}

Received May 20, 2019; Accepted October 23, 2019

DOI: 10.3892/ijo.2019.4914

\begin{abstract}
Ski, an evolutionary conserved protein, is involved in the development of a number of tumors, such as Barrett's esophagus, leukemia, colorectal cancer, gastric cancer, pancreatic cancer, hemangiomas and melanoma. However, studies on the functions of Ski in osteosarcoma (OS) are limited. In this study, firstly the differential expression of Ski in OS tissues and osteochondroma tissues was detected, and the expression of Ski in both human OS cell lines (MG63 and U2OS) and normal osteoblasts (hFoB1.19) was then detected. The results demonstrated that Ski expression was significantly upregulated in both human OS tissues and cell lines. The results led us to hypothesize that Ski may play an essential role in the pathological process of OS. Thus, Ski specific small interfere RNA (Ski-siRNA) was used. The results revealed that OS cell proliferation was markedly inhibited following the knockdown of Ski, which was identified by CCK8 assay, EdU staining and cell cycle analysis. In addition, OS cell migration was significantly suppressed following Ski knockdown, which was identified by wound healing assay. Moreover, the protein levels of p-PI3K and p-Akt in OS cells declined prominently following Ski knockdown. On the whole, the findings of this study revealed that Ski expression was significantly upregulated in OS tissue and OS cells. The knockdown of Ski decreased OS cell proliferation and migration, which was
\end{abstract}

Correspondence to: Dr Pengde Kang, Department of Orthopadic Surgery, West China Hospital, Sichuan University, 37 Wainan Guoxue Road, Chengdu, Sichuan 610041, P.R. China

E-mail: kangpengde1969@163.com

Dr Meng Tian, Neurosurgery Research Laboratory, West China Hospital, Sichuan University, Chengdu, Sichuan 610041, P.R. China E-mail: tianmong007@gmail.com

*Contributed equally

Key words: Ski, osteosarcoma, proliferation, migration, PI3K/Akt signaling pathway mediated by blocking the PI3K/Akt signaling pathway. Thus, Ski may act as a tumor promoter gene in tumorigenesis, and Ski may prove to be a potential therapeutic target for the treatment of OS.

\section{Introduction}

Osteosarcoma (OS), a malignant primary tumor, is one of the most common primary bone tumors and mainly generates in teenagers (1). OS originates from primitive bone-forming mesenchymal stem cells and is usually associated with an aggressive behavior and growth speed, a high local recurrence rate and a high metastatic potential $(2,3)$. With the improvement of medical technology, the 5-year survival rate for patients with local OS remains at $70 \%$, while for patients with metastasis it remains at merely $20 \%$ (4). Over the past decades, no marked improvements have been made in OS therapy (at least to the best of our knowledge) and this is mainly due to local recurrence or distant metastasis (5). Thus, the study of the molecular mechanisms of OS tumorigenesis is imperative, as well as the exploration of novel biomarkers for the early diagnosis of OS.

The Ski oncogene was first isolated from the avian Sloan-Kettering viruses, and its expression can induce the transformation of chicken embryo fibroblasts, and its oncogenic activity is achieved through the inhibition of the transforming growth factor- $\beta$ (TGF- $\beta$ )/Smad signaling pathway (6-8). A number of studies have proven that Ski expression is notably upregulated in some human cancer cell lines and is associated with a number of advanced stages tumors, including Barrett's esophagus (9), colorectal cancer (10), gastric cancer (11), pancreatic cancer $(12)$ and melanoma $(13,14)$. However, the exact function of Ski in human OS and the underlying mechanisms in tumorigenesis remain unclear.

In this study, we concentrated on revealing the roles of Ski in OS and the underlying mechanisms. We found that Ski was over expression in OS tissues and cell lines. Moreover, the knockdown of Ski decreased OS cell proliferative and migratory abilities, and these effects may be mediated via the inhibition of the PI3K/Akt signaling pathway. These findings indicate that Ski may prove to be a potential therapeutic target in the treatment of OS. 


\section{Materials and methods}

OS samples. The study protocol was specifically approved by the Ethics Committee of West China Hospital of Sichuan University (Chengdu, China) and complied with the Declaration of Helsinki. A total of 6 OS tissue samples and 6 osteochondroma tissue samples were collected during surgery from patients between October 1, 2017 and December 31, 2018, and the patient information is presented in Table I. No patients had received radiotherapy or chemotherapy prior to surgery. All patients provided written informed consent and agreed to participate in this research. All collected tissues were frozen instantly in liquid nitrogen following resection and were preserved in an ultralow temperature refrigerator prior to use in the experiments.

Immunohistochemistry (IHC) analysis. The expression of Ski in both OS tissues and osteochondroma tissues was detected by IHC under the standard immunoperoxidase staining procedure. In brief, the tissues were embedded with paraffin and conventionally sliced into $4-\mu \mathrm{m}$-thick sections. The sections were baked for $2 \mathrm{~h}$ at $60^{\circ} \mathrm{C}$ before being dewaxed in xylene, and were then rehydrated through graded ethanol, and subsequently placed in sodium citrate buffer $(\mathrm{pH}$ 6.0) and heated up to $100^{\circ} \mathrm{C}$ for $5 \mathrm{~min}$ for antigen repair. After cooling down, the sections were incubated with 5\% goat serum (Solarbio) at $37^{\circ} \mathrm{C}$ for $30 \mathrm{~min}$, and the sections were then incubated with rabbit anti-human Ski monoclonal antibodies (1:200; sc-33693, Santa Cruz Biotechnology) at $4^{\circ} \mathrm{C}$ overnight, and then incubated with the secondary antibody $(1: 1,000$; biotinylated goat anti-mouse $\operatorname{lgG}, \mathrm{ZB}-2305$; ZSBIO) at $37^{\circ} \mathrm{C}$ for $1 \mathrm{~h}$. The sections were developed with diaminobenzidine (DAB; Beyotime Biotechnology) to detect the bound antibody. After staining, the sections were sealed up with balsam before observation using an optical microscope (Olympus Optical). The brownish-yellow presented in cytoplasm or cytomembrane indicated positive results, or otherwise indicated negative results. Five fields were randomly selected for detection to calculate the positive expression. The experiment was performed 3 times.

Cell lines and cell culture. All the cell lines were purchased from the Cellular Center of Institute of Basic Medical Sciences. Human OS cell lines, including MG63 and U2OS were cultured in Eagle's minimum essential medium containing 10\% fetal bovine serum (FBS; Gibco; Thermo Fisher Scientific). The human normal osteoblasts (hFOB1.19) were cultured in Dulbecco's modified Eagle's medium/F12 (DMEM/F12; HyClone) containing 10\% FBS (Gibco; Thermo Fisher Scientific) and 1\% streptomycin and penicillin (Gibco; Thermo Fisher Scientific). The cells were cultured in a humidified atmosphere in $\mathrm{CO}_{2}$ cell incubator $\left(37^{\circ} \mathrm{C}, 5 \% \mathrm{CO}_{2}\right)$.

Western blot analysis. The protein samples were extracted from the tissues or cells using RIPA lysis buffer (990 $\mu \mathrm{l}$ RIPA and $10 \mu \mathrm{l}$ phenylmethylsulfonyl fluoride; Beyotime) on the ice. The supernatants were then transferred into a new $1.5 \mathrm{ml}$ centrifuge tube and centrifuged in a low temperature environment for $15 \mathrm{~min}$ at $17,900 \mathrm{x} \mathrm{g}$, and insoluble material was discarded. The sample concentration was detected using the BCA kit (Beyotime). The protein samples $(20 \mu \mathrm{g})$ were separated by 10 or $12 \%$ SDS-PAGE, and the proteins were then transferred onto PVDF membranes ( $0.45 \mu \mathrm{m}$; Millipore) using a transfer unit (Bio-Rad). Thereafter, the membranes were blocked in TBS solution containing 5\% BSA for $2 \mathrm{~h}$ at room temperature. The membranes were then incubated with primary antibodies including anti-Ski (mouse, 1:200, sc-33693; Santa Cruz Biotechnology), proliferating cell nuclear antigen (PCNA; 1:1,000, 10205-2-AP, rabbit; Proteintech), CDK4 (sc-23896), cyclin D1 (sc-450) (both mouse, 1:500; Santa Cruz Biotechnology), matrix metalloproteinase (MMP)2 (4022S), MMP9 (3852S) (both rabbit, 1:1,000; Cell Signaling Technology), PI3K (4292S), p-PI3K (4228S), Akt (9272S) (all rabbit, 1:1,000; Cell Signaling Technology), p-Akt (4060S, rabbit, 1:2,000; Cell Signaling Technology) and $\beta$-actin (TA09, mouse, 1:1,000; ZSBIO) overnight at $4^{\circ} \mathrm{C}$. Following washing with TBST, the membranes were then incubated with secondary antibodies (ZB-2301 and ZB2305, 1:10,000; ZSBIO) for $1 \mathrm{~h}$. After washing with TBST 3 times, the proteins on the membranes were visualized by ECL, and the results were scanned by Quantity One software (Bio-Rad).

Immunofluorescence staining. The cells were cultured on small coverslips and allowed to adhere. Thereafter, the cells were washed with PBS solution for 5 min each, then fixed with $4 \%$ paraformaldehyde for $30 \mathrm{~min}$, and washed with PBS for 5 min each. The cells were then permeabilized with $0.3 \%$ Triton X-100 for $20 \mathrm{~min}$, and washed in PBS for 5 min each. The cells were blocked for 30 min with $10 \%$ goat serum at $37^{\circ} \mathrm{C}$, and thereafter, anti-Ski (sc-33693, anti-human 1:300; Santa Cruz Biotechnology); antibodies were added followed by incubation overnight at $4^{\circ} \mathrm{C}$. The following day, the cells were washed in PBS 3 times, and then incubated with secondary antibodies (Alexa Fluor 488-conjugated anti-mouse, 1:300; A21202; Invitrogen; Thermo Fisher Scientific) for $2 \mathrm{~h}$ at room temperature. Finally, the samples were incubated with DAPI for $10 \mathrm{~min}$ at room temperature. The images were acquired with a fluorescence microscope (Zeiss; Carl Zeiss).

Transfection assay. Ski specific siRNA (Ski-siRNA) and scrambled sequence siRNA (negative control siRNA, NC-siRNA) were purchased from Thermo Fisher Scientific. The target sequence of Ski-siRNA was 5'-CGGACCTTGGCTGGTTCC TCCAATA-3', and the sequence of 5'-TTCTCCGAACGTGTC ACGT-3' was considered to be NC-siRNA. The MG-63 and U2OS cells were transfected with Ski-siRNA or NC-siRNA using Lipofectamine ${ }^{\circledR}$ RNAiMAX Reagent (Thermo Fisher Scientific) in accordance with the manufacture's protocol. Following $48 \mathrm{~h}$ of transfection, the cells were collected for the used in the following experiments. Western blot analyses were used to assess the silencing effect of Ski-siRNA. The cells were pre-treated with basic culture medium DMEM/F12 with or without $50 \mu \mathrm{M}$ LY294002 (a specific PI3K inhibitor, S1737, Beyotime) for $6 \mathrm{~h}$ prior to transfection.

Proliferation assay in vitro. Cell Counting kit-8 (CCK-8) assays (Dojindo) were used to assess cell proliferation. In brief, at $48 \mathrm{~h}$ following transfectiong with Ski-siRNA and NC-siRNA, the cells were trypsinized, and then replanted into 
Table I. Clinical profles of the 12 patients with osteosarcoma and osteochondroma.

\begin{tabular}{lcc}
\hline $\begin{array}{l}\text { No. of } \\
\text { plinicopathological }\end{array}$ & $\begin{array}{c}\text { No. of } \\
\text { osteosarcoma } \\
\text { patients }(\mathrm{n}=6)\end{array}$ & $\begin{array}{c}\text { osteochondroma } \\
\text { patients }(\mathrm{n}=6)\end{array}$ \\
\hline
\end{tabular}

Sex

\begin{tabular}{lcc} 
Male & 3 & 4 \\
Female & 3 & 2 \\
Age, years & & 17 \\
Median & 38 & $13-52$ \\
Range & $10-49$ & \\
Tumor location & & 4 \\
Femur & 3 & 2 \\
Tibia and fibula & 2 & 0 \\
Others & 1 & \\
Enneking stage & & - \\
I /II A & 2 & - \\
IIB/III & 4 & - \\
Metastasis & & - \\
Yes & 4 & \\
No & 2 & \\
\hline
\end{tabular}

96-well plates with $3 \times 10^{3}$ cells/well for the cell proliferation assay. This was followed by the addition of DMEM (100 $\mu \mathrm{l})$ containing $10 \mu \mathrm{l}$ of CCK-8 working solution to each well at corresponding time-points and incubation at $37^{\circ} \mathrm{C}$ for $3 \mathrm{~h}$ in an incubator. Following incubation, cell viability was determined by measuring the absorbance at $450 \mathrm{~nm}$ using a microplate reader (Bio-Rad).

The EdU reagent kit (Ribobio) was also used to evaluate cell proliferation based on our previous study (15). Briefly, the OS cells were transfected with siRNA for $48 \mathrm{~h}$ and the medium was then changed with culture medium to continue culture for 2 and 4 days. The cells were then incubated with complete medium solution containing $50 \mathrm{M}$ EdU for $1 \mathrm{~h}$ at corresponding time-points. The following procedure was carried out in accordance with the manufacture's protocol. Finally, images were acquired with a fluorescence microscope (Zeiss; Carl Zeiss).

Cell cycle analysis. The OS cells were planted in a cell culture plate $(35 \mathrm{~mm})$ with $3 \times 10^{5}$ cells and then incubated overnight until 50-70\% confluent. Prior to transfection, the cells were synchronized for $6 \mathrm{~h}$ in serum-free DMEM culture medium. At $48 \mathrm{~h}$ following transfection with siRNA, the cells were trypsinized and transferred to a $10 \mathrm{ml}$ centrifuge tube (centrifugation at $200 \mathrm{x} \mathrm{g}$ for $5 \mathrm{~min}$ at $4^{\circ} \mathrm{C}$, washed with cold PBS solution twice, fixed with $70 \%$ pre-cold ethanol overnight at $-20^{\circ} \mathrm{C}$. Subsequently, $190 \mu 1$ EDTA and $10 \mu 1$ Rnase A ( $1 \mathrm{mg} / \mathrm{ml})$ were added to tubes for $5 \mathrm{~min}$ at room temperature, and $18 \mu \mathrm{l}$ propidium iodide and $97 \mu \mathrm{l}$ PBS were then added for $10 \mathrm{~min}$ at $4^{\circ} \mathrm{C}$ in the dark, respectively. The volume was adjusted to $1 \mathrm{ml}$ with PBS. Subsequently, the percentage of cells cycle was analyzed using a BD FACSCan (BD Biosciences).
Wound healing assay. Wound healing assay was performed to estimate the OS cell migratory activities. The transfected OS cells were plated into a 6-well plate at a density of $5 \times 10^{5}$ cells/well and two horizontal lines were marked on the back of the well plate. When the confluence of the cells reached $100 \%$, the cells were scratched with a sterile $100 \mu 1$ pipet tip, and the cells debris was then removed using PBS solution. Following the addition of serum-free medium containing $2 \%$ FBS, the cells were placed back into the incubator $\left(37^{\circ} \mathrm{C}, 5 \% \mathrm{CO}_{2}\right)$ for $48 \mathrm{~h}$. The migration of the cells was photographed under a microscope with Zen Imaging software at $0,12,24$ and $48 \mathrm{~h}$ after scratching. The percentage of wound healing was determined as described in our previous study (16).

Statistical analysis. Statistical analysis was performed using SPSS 21.0 software (IBM). All data are expressed as the means \pm SD. Statistical significance between two groups were analyzed with the Student's t-test. The significance among multiple groups was using one-way ANOVA followed by Tukey's post hoc test. P-values $<0.05$ were considered to indicate statistically significant differences. Each experiment was carried out in triplicate.

\section{Results}

Ski is highly expressed in OS tissues and cell lines. Compared with the osteochondroma tissues, Ski was more highly expressed in the OS tissues. As shown in Fig. 1A and B, Ski was overexpressed in OS tissues, whereas its expression was hardly detected in the osteochondroma tissues by immunohistochemistry. The results of western blot analysis also demonstrated that Ski (the molecular weight of Ski varies between 90 and $132 \mathrm{kDa}$ ) increased significantly in the OS sample tissues compared with the osteochondroma samples (Fig. 1C and D). These results indicated that Ski may play an essential role in the tumorigenesis of OS. Thus, we compared Ski expression level in OS cell lines (MG63 and U2OS) with hFOB1.19 normal osteoblast cells. The results of immunofluorescence staining revealed that Ski expression was more abundant in the OS cell lines compared with the osteoblasts (Fig. 2A). Furthermore, western blot analysis confirmed the results again (Fig. 2B).

Ski knockdown decreases the proliferation of OS cells. In order to examine the role of Ski in OS cells, a specific siRNA (Ski-siRNA) was applied in the OS cell lines, MG63 and U2OS cells. The results indicated that Ski expression was inhibited efficiently in the MG63 and U2OS cells (Fig. 3A and D). Subsequently, CCK-8 assay was performed to investigate the effects of Ski-siRNA on OS cell proliferation. The results revealed that OS cell proliferation was markedly suppressed following transfection with Ski-siRNA at 48 and $72 \mathrm{~h}$ in the MG63 cells $(\mathrm{P}<0.001)$ compared with the control group and NC-siRNA group (Fig. 3E), and similar results were obtained with the U2-OS cells (Fig. 3F). In addition, EdU kit assay was applied to investigate the OS cell proliferative ability, and the results indicated that the MG63 and U2-OS cell proliferative ability was inhibited significantly following the knockdown of Ski (Fig. 4A-D). Moreover, to further confirm the results 
A
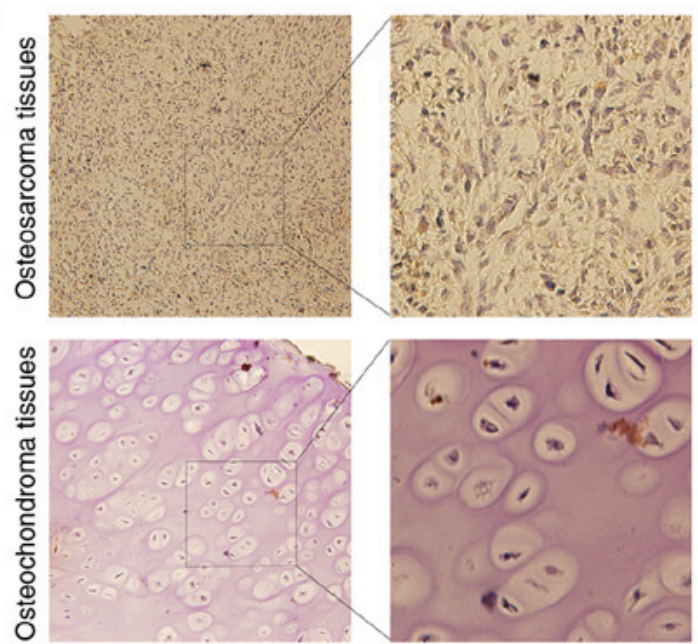

C

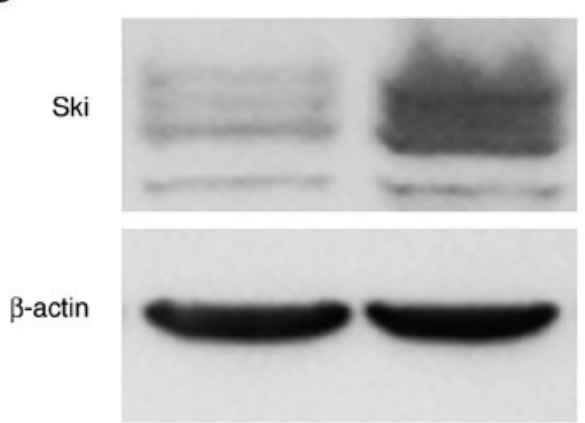

B

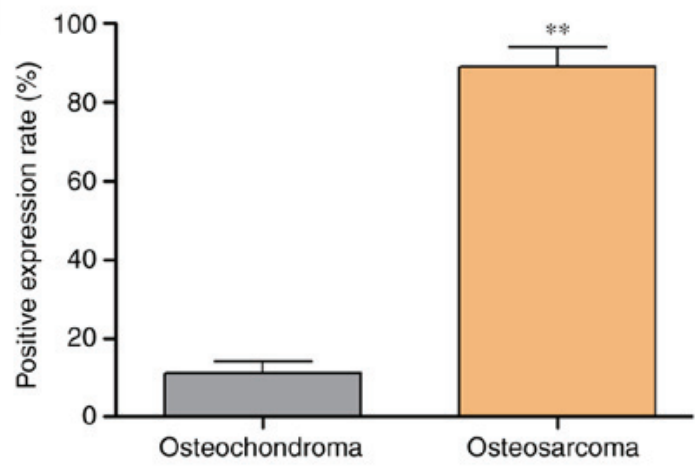

D

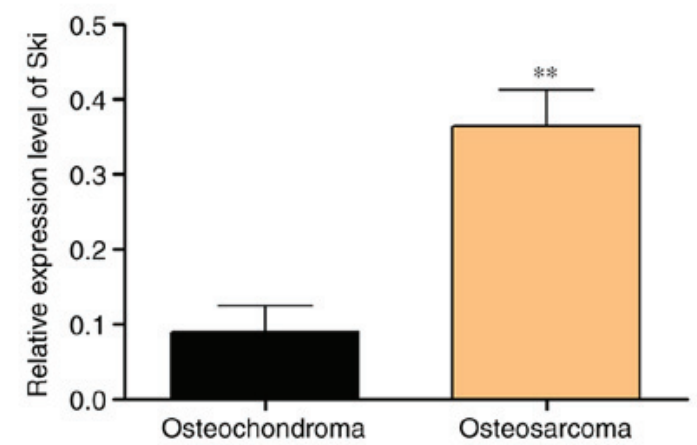

Figure 1. Ski expression in OS and OC tissue samples. (A) Immunohistochemical Ski protein staining results in OS and OC tissue samples. (B) Positive Ski expression rate in OS and OC tissue samples. (C) The protein expression of Ski in OS and OC tissue samples detected by western blot analysis. (D) Statistical analysis of Ski expression in OS and OC tissue samples. Values are expressed as the means \pm SD ( $n=3)$. ${ }^{* *} \mathrm{P}<0.001$ compared with $\mathrm{OC}$ tissue samples). OS, osteosarcoma; OC, osteochondroma.

A

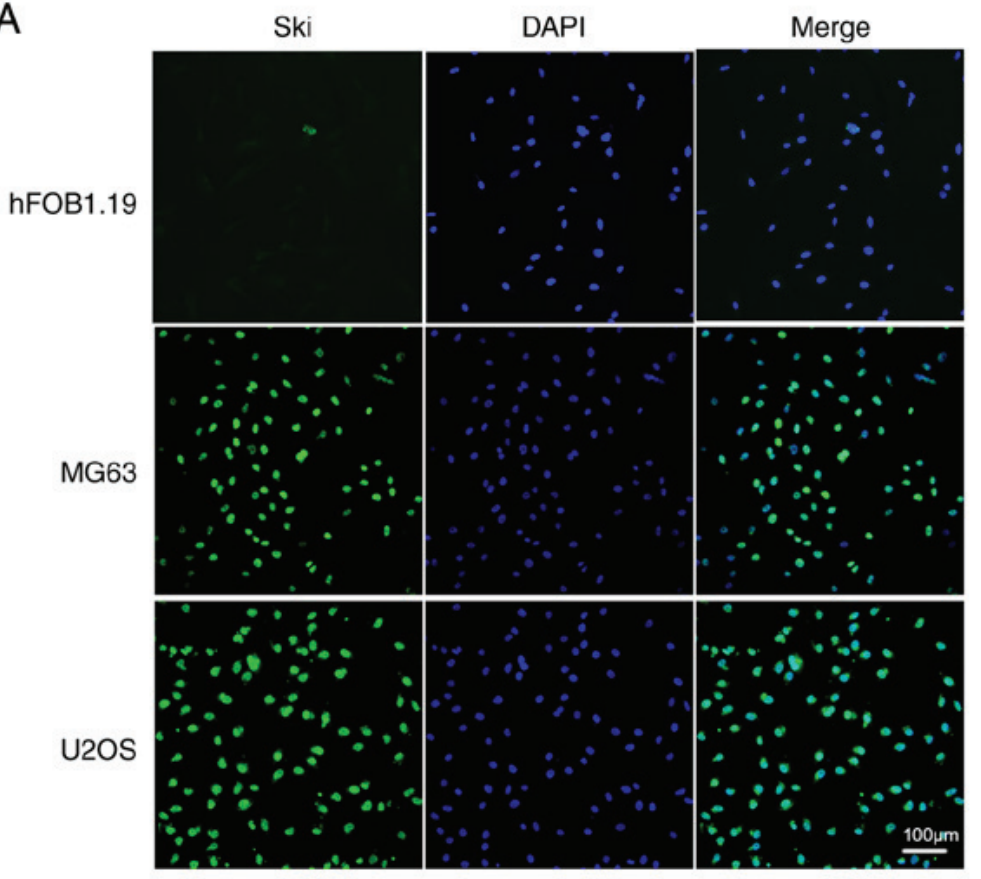

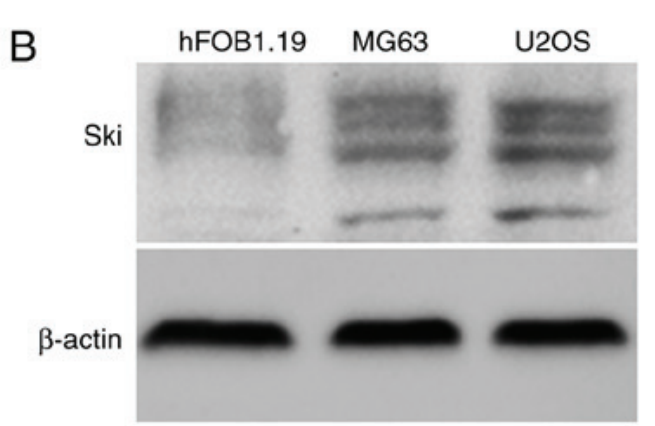

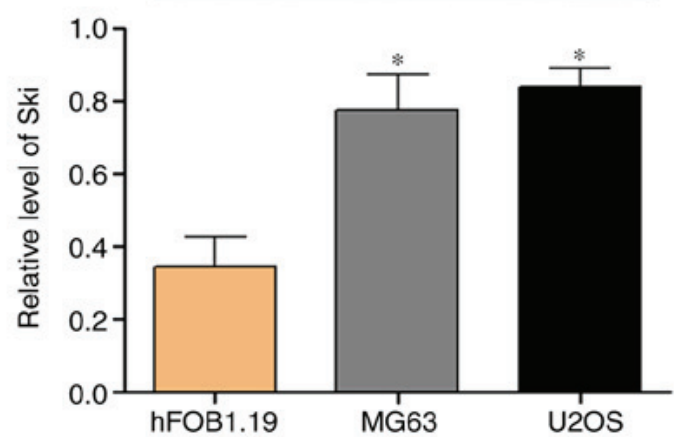

Figure 2. Ski is upregulated in OS cell lines. (A) Immunofluorescence staining showing that the fluorescence intensity of Ski was highly increased in OS cell lines (MG63 and U2OS) compared with the normal osteoblasts (hFOB1.19). Scale bars, $100 \mu$ m. (B) Western blot analysis was performed to determine the expression Ski in the OS cell lines (MG63 and U2OS) and in normal osteoblasts (hFOB1.19); the expression of Ski was significantly upregulated in OS cell lines. No significant differences were observed between MG63 and U2OS cells ( $\mathrm{n}=3)$. ${ }^{*} \mathrm{P}<0.05$ compared with hFOB1.19 normal osteoblasts). OS, osteosarcoma. 
A

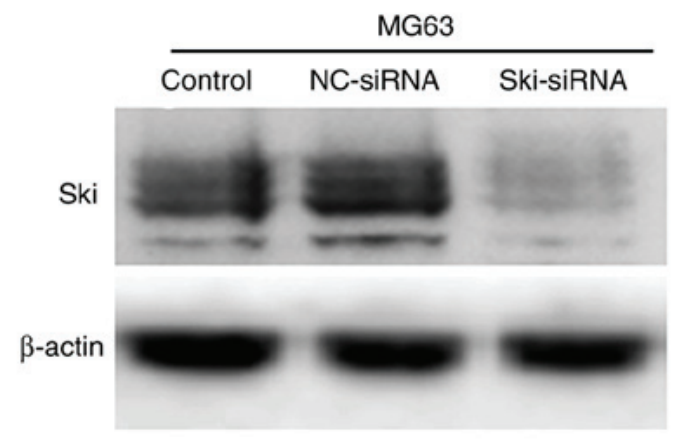

C

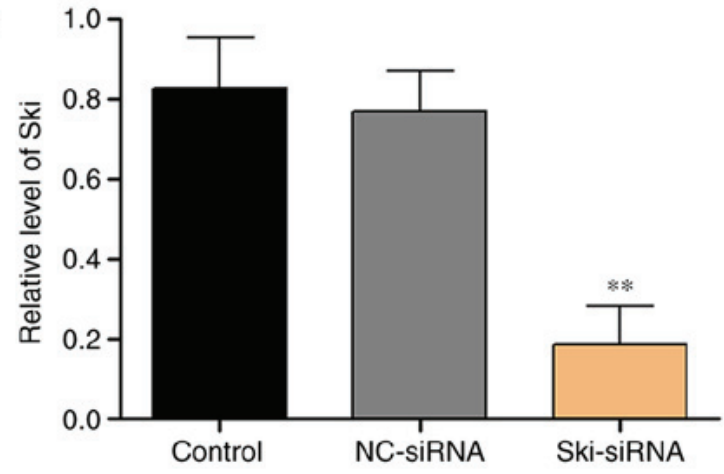

$E$

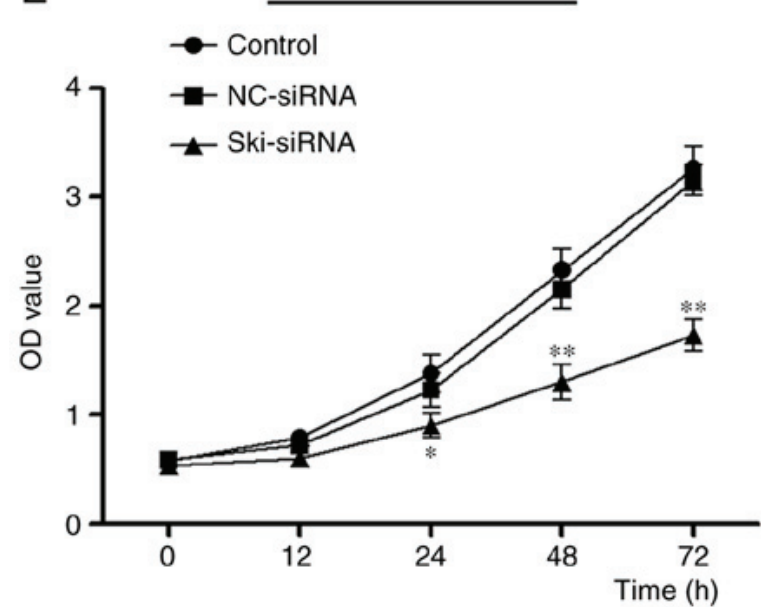

B
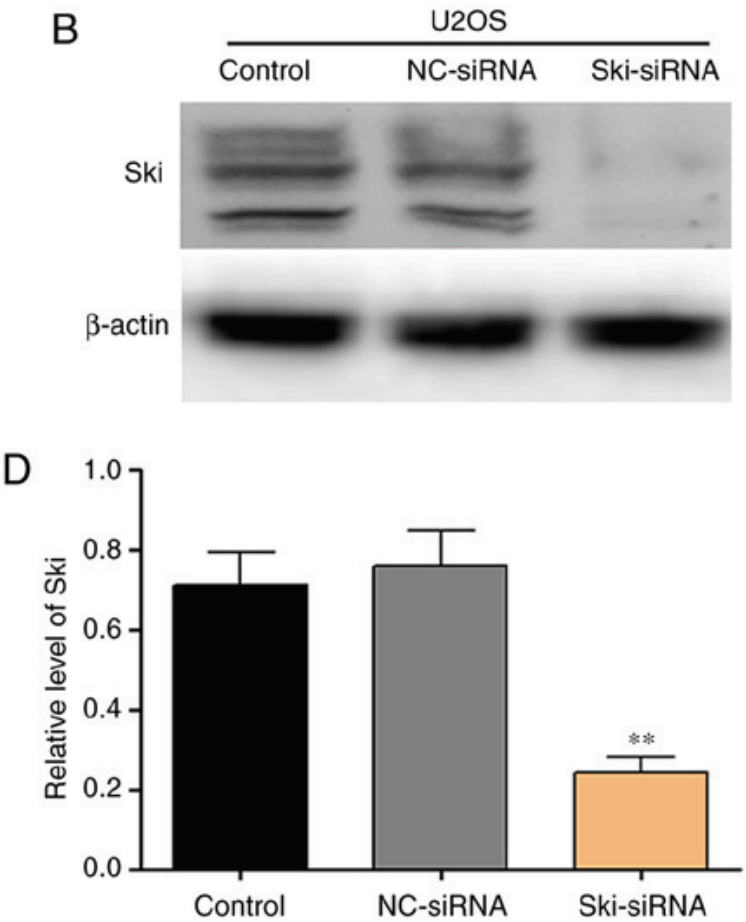

$\mathrm{F}$

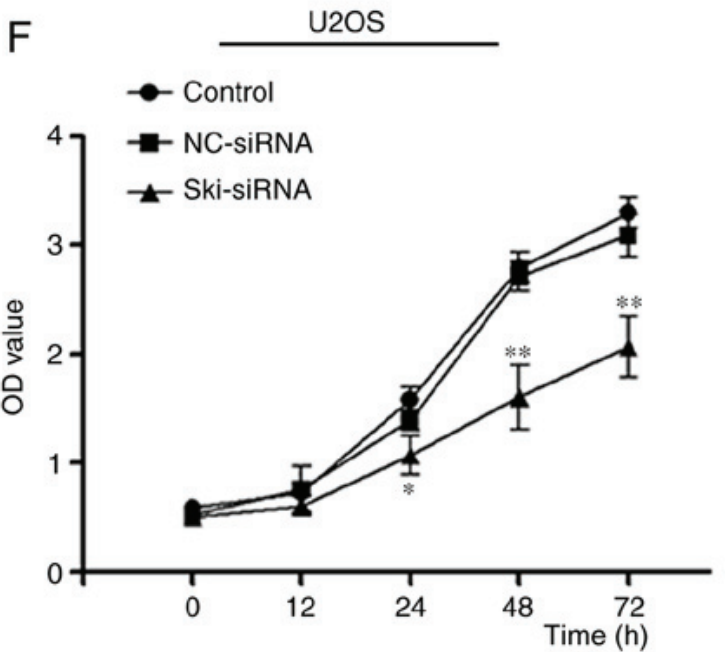

Figure 3. OS cells were transfected with Ski-siRNA for $48 \mathrm{~h}$, and western blot analysis was used to detect Ski expression following transfected with Ski-siRNA. (A) The expression of Ski in MG63 was significantly decreased following transfection with Ski-siRNA. (B) The expression of Ski in U2OS was significantly decreased following transfection with Ski-siRNA. (C) Statistical analysis of Ski/ $\beta$-actin following the knockdown Ski in MG63 cells. (D) Statistical analysis of Ski/ $\beta$-actin following the knockdown Ski in U2OS cells. (E) MG63 cell proliferation was assessed by CCK8 assay at 12, 24, 48 and $72 \mathrm{~h}$ following transfection. (F) U2OS cell proliferation was assessed by CCK8 assay at 12, 24, 48 and $72 \mathrm{~h}$ following transfection. Values are expressed as the means $\pm \mathrm{SD}(\mathrm{n}=3)$. "P<0.05, ${ }^{* *} \mathrm{P}<0.001$ vs. the control or NC-siRNA group). OS, osteosarcoma.

mentioned above, the proportions of cell cycle profiles were investigated following transfection with Ski-siRNA by flow cytometry. The results revealed that, the percentage of MG63 cells at the G1 phase increased significantly, while the percentage at the G2/M phase decreased in the Ski-siRNA group compared with the NC-siRNA group (Fig. 4E and G); however, no significant difference was observed in the cells in the S phase. Similar results were obtained for the U2OS cells (Fig. 4F and H). Furthermore, the results of western blot analysis revealed that the expression of proliferation-related proteins, including PCNA, CDK4 and cyclin D1 decreased significantly following transfection with Ski-siRNA in OS cells (Fig. 5). All the above-mentioned results strongly indicate that Ski plays a crucial role in the proliferation of OS cells.

Ski knockdown decreases the migration of OS cells. In addition to proliferation, OS cell migration also plays a critical role in tumor metastasis. Thus, in this study, a wound healing assay was performed to assess the effects of Ski knockdown on MG63 and U2OS cell migration. Following the knockdown of Ski, the percentages of MG63 cells after wound healing at $48 \mathrm{~h}$ in the NC-siRNA group and Ski-siRNA group were $94.47 \pm 5.36$ and $52.53 \pm 6.57 \%$, respectively, and the rate of wound healing in the Ski-siRNA group was much lower than that of the NC-siRNA group (Fig. 6A and B); similar results 
A

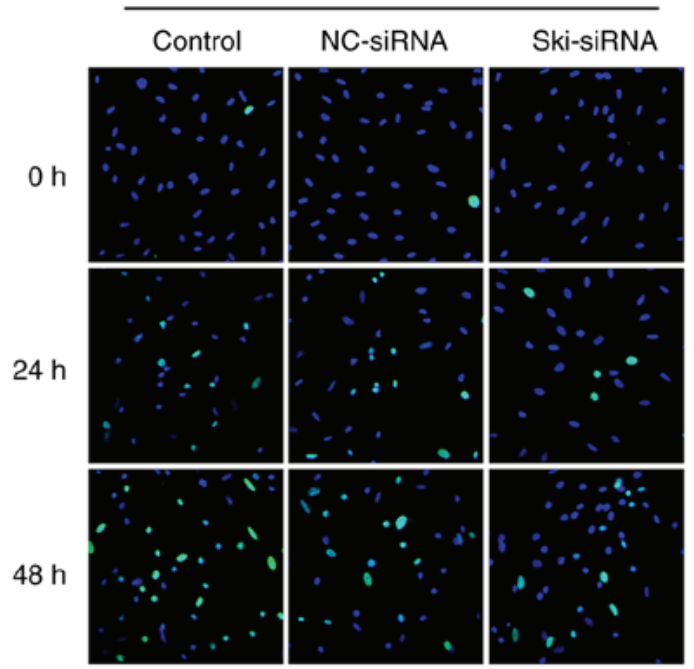

C

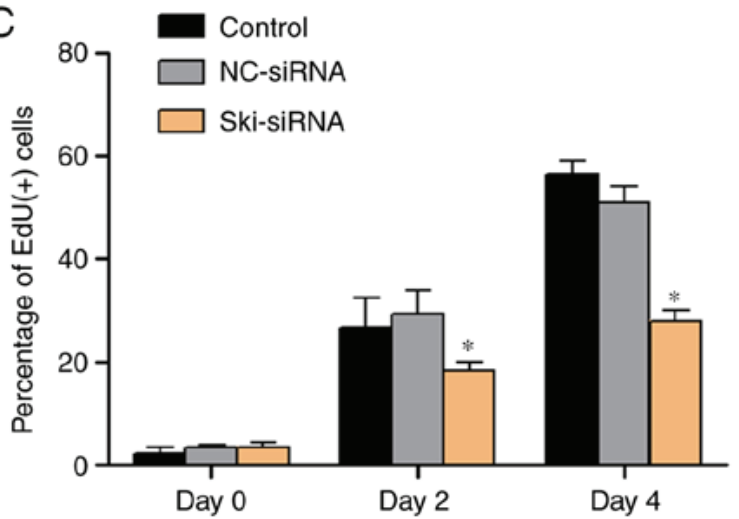

B

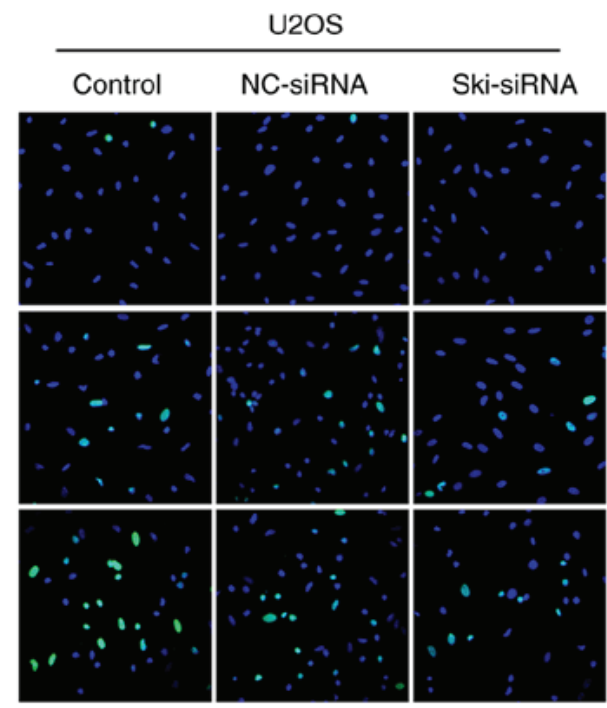

D

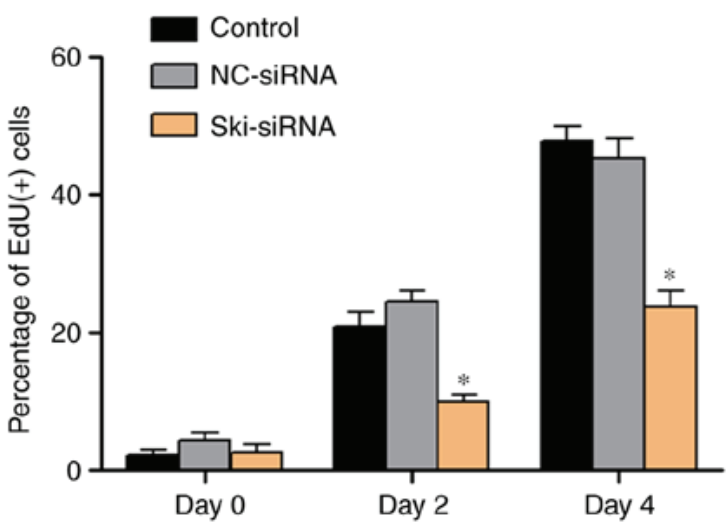

Figure 4. EdU staining assay and cell cycle distribution were employed to detect the cell proliferation rates following transfection. (A) Proliferation rates of MG63 cells among the control, NC-siRNA and Ski-siRNA groups at 24 and $48 \mathrm{~h}$ following transfection. (B) Proliferation rate of U2OS cells among the control, NC-siRNA and Ski-siRNA groups at 24 and $48 \mathrm{~h}$ following transfection. (C) Statistical analysis of percentages of EdU-positive MG63 cells in each group for corresponding time-points. (D) Statistical analysis of percentages of EdU-positive U2OS cells in each group for corresponding time-points. Data are shown as the means $\pm \mathrm{SD} .{ }^{*} \mathrm{P}<0.05$ compared with control or NC-siRNA groups.

were obtained for the U2OS cells as well (Fig. 6A and C). In addition, the results of western blot analysis revealed that the expression of migration-related proteins, including MMP2 and MMP9 markedly decreased following the knockdown of Ski (Fig. 7).

Ski knockdown suppresses the activation of the PI3K/Akt signaling pathway in OS cells. The PI3K/Akt signaling pathway plays an essential role in tumorigenesis, which has been well expounded as an essential pathway for the proliferation and migration of OS cells. Thus, in this study, the effects of Ski on the certain molecules which are involved in the PI3K/Akt signaling pathway in MG63 and U2-OS cells were examined. The results revealed that the knockdown of Ski decreased the PI3K and Akt phosphorylation levels significantly in the MG63 cells compared with the control and NC-siRNA groups (Fig. 8A). Similar results were obtained in the U2OS cells (Fig. 8B). Furthermore, to verify the function of the PI3K/Akt pathway, we examined the effects of the LY294002 on the Ski-mediated proliferation and migration of OS cells. The results revealed that LY294002 significantly enhanced the inhibitory effects of Ski-siRNA on OS cell proliferation and migration, and these results were further verified by CCK8 assay (Fig. 8C and D) and wound healing assay (Fig. 8E and F).

\section{Discussion}

OS, as a malignant bone tumor, mainly occurs in children and young individuals $(17,18)$. With the development of new therapeutic technologies, the survival rate of patients with OS has markedly increased. However, the overall outcome of patients with OS remains poor due to drug or multidrug resistance $(19,20)$. Thus, the study of the mechanisms responsible for the development of OS and the identification of novel effective treatable methods for patients with OS is crucial.

Ski, as an evolutionary conserved protein, has been reported to exist in various tissues and species, and participates in diverse cellular processes, such as cell proliferation, metastasis, transformation and tumor progressions (6). Previous studies have demonstrated that Ski plays an essential role in certain pathophysiological processes, such as wound healing and astrocyte proliferation $(15,21)$, vascular smooth muscle cell proliferation $(22,23)$, muscle differentiation $(24,25)$ and liver regeneration (26). Notably, Ski, as a novel therapeutic 

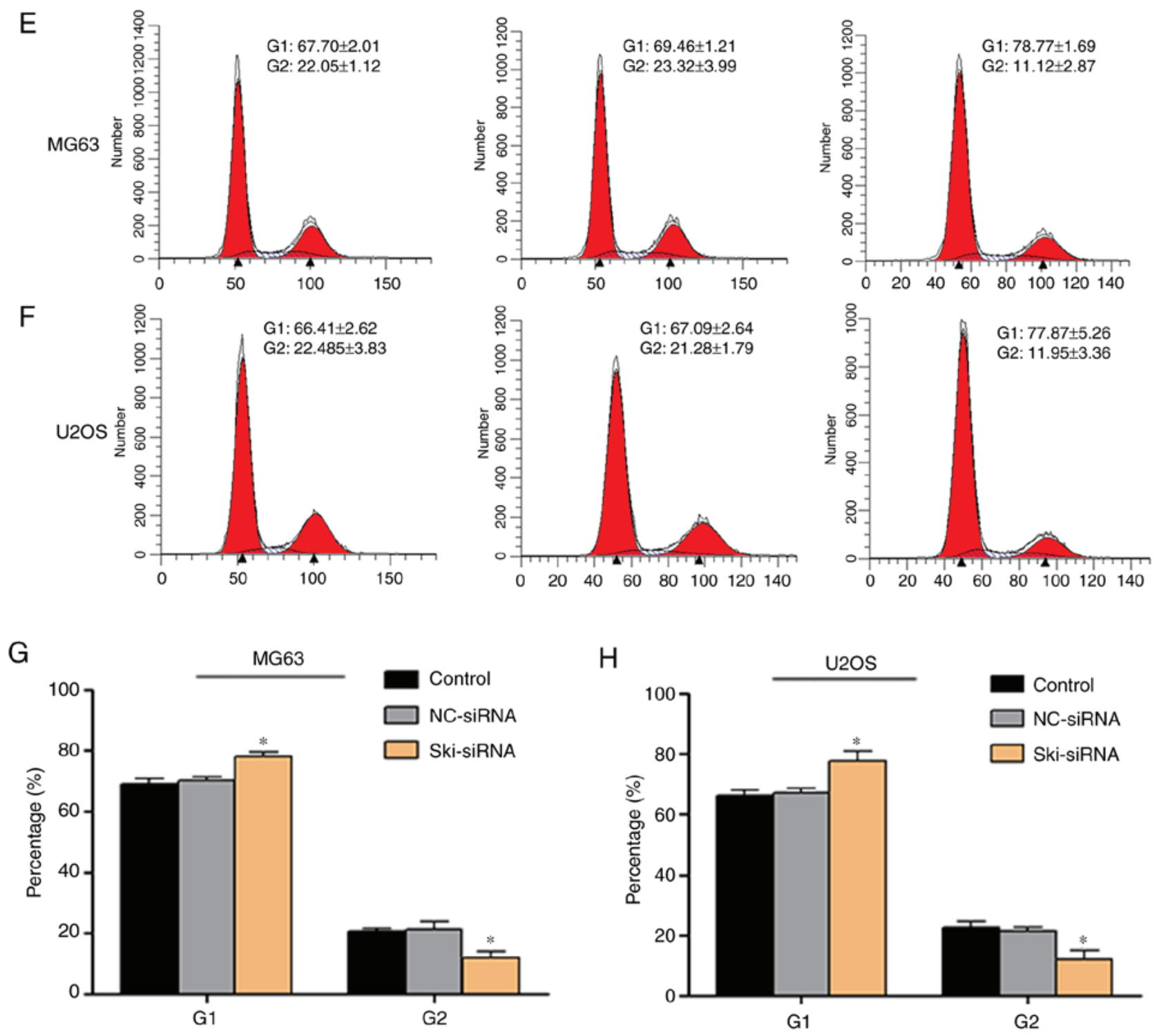

Figure 4. Continued. (E) The cell cycle distribution of MG63 was examined by flow cytometry. (F) The cell cycle distribution of U2OS was examined by flow cytometry. (G) Bar chart shows the average data of cell cycle distribution of MG63. (H) Bar chart shows the average data of cell cycle distribution of U2OS. Data are shown as the means $\pm \mathrm{SD}$. ${ }^{*} \mathrm{P}<0.05$ compared with control or NC-siRNA groups.

target, has been found over expression in the development of solid tumors (27). However, the function and roles of Ski in human OS remain largely unknown. The present study focused on investigating Ski expression and its roles in OS cell lines.

In this study, we have found that Ski expressed much more in OS tissues sample compared with osteochondroma samples. Similarly, Ski expression was also more abundant in MG63 and $\mathrm{U} 2 \mathrm{OS}$ cell lines compared with normal osteoblast cell line. However, the low sample size was a limitation to the present study. A previous study demonstrated that the Ski expression level ws markedly increased during human melanoma tumor progression $(13,28)$. Wang et al demonstrated that Ski was overexpressed in pancreatic cancer cell lines and that Ski may act as a tumor proliferation-promoting factor in pancreatic cancer (29). Combined with our results, therefore, we highly suspected that Ski may play a vital role in the pathological process of OS.

To the best of our knowledge, the definite role of Ski in OS has not yet been extensively studied. This study provides the first evidence that Ski definitely plays an important role in OS. In the present study, we demonstrated that the knockdown of Ski decreased OS cell line proliferation verified by CCK8 assay and EdU staining assay. Moreover, the expression of proliferation-association proteins, including PCNA, CDK4 and cyclin D1 was downregulated in OS cells following transfection with Ski-siRNA. Furthermore, OS cell cycle arrest in the G1/G0 phase occurred following the knockdown of Ski. Atanasoski et al demonstrated that Ski controls the proliferation of Schwann cell and myelination process (30). Zhao et al also revealed that Ski plays a vital role in the proliferation of astrocyte and astrogliosis process (16). Both of these studies demonstrated that Ski participates in several types of cell proliferation biological properties. Combined with the findings of the present study, it is thus proven that Ski is positively associated with the proliferation of OS cell lines.

OS cell proliferation plays a vital role in tumor metastasis, while migration is also a critical step for tumor metastasis (31). In the present study, OS cell migration markedly decreased 
A
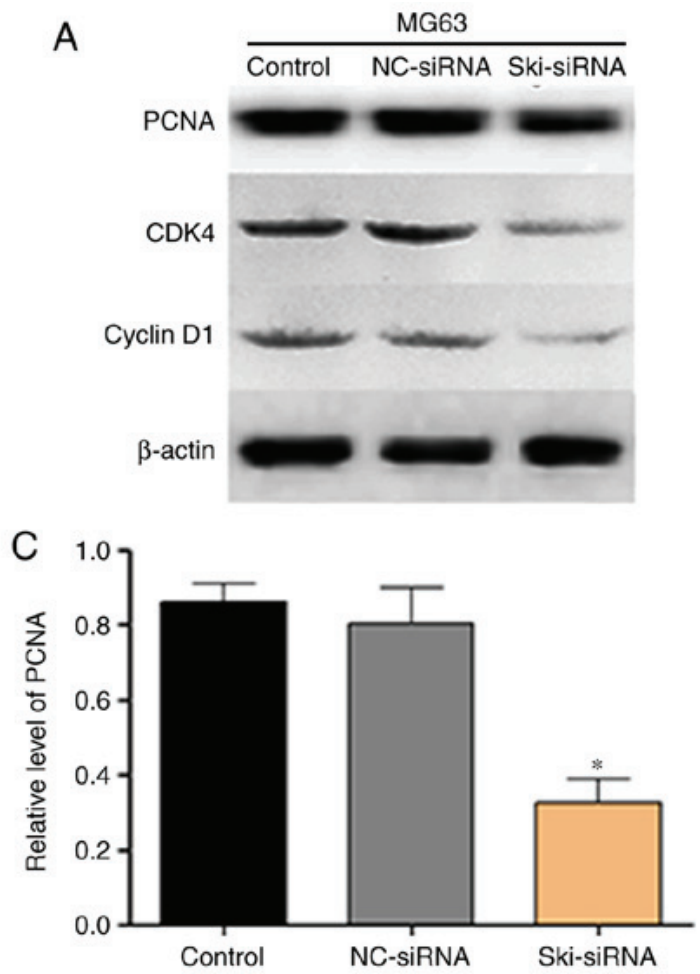

E
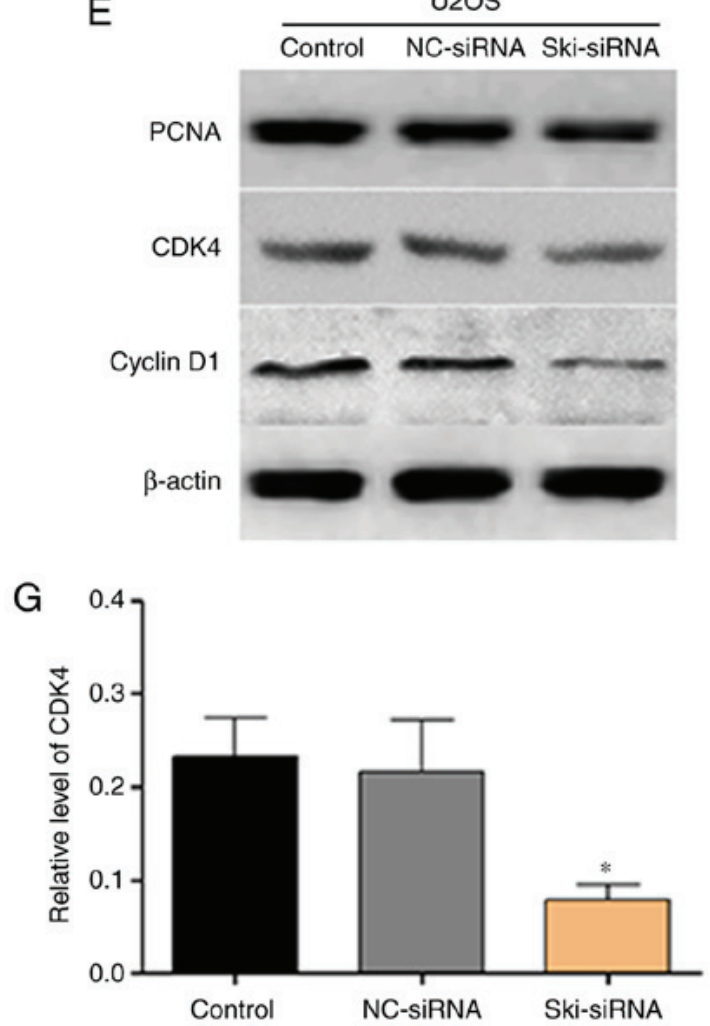

B

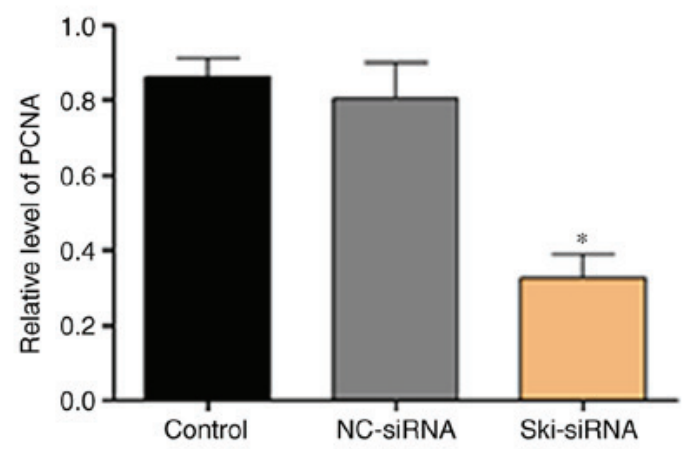

D

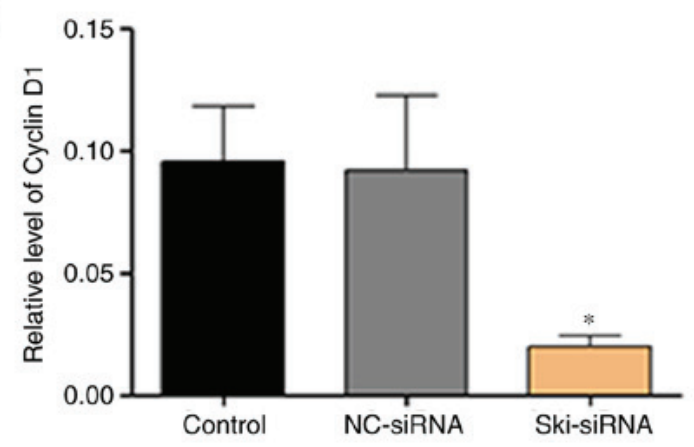

F

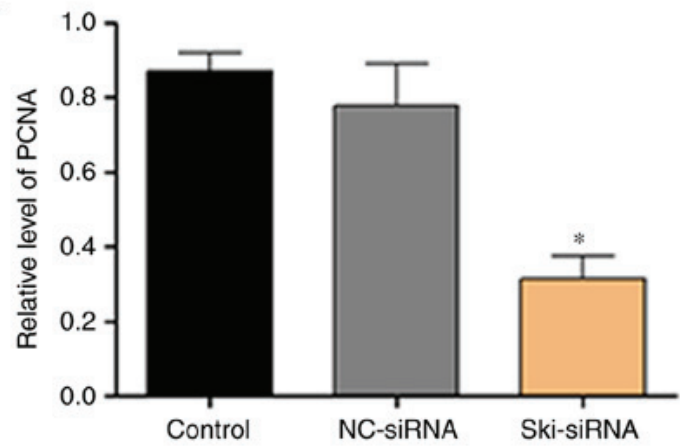

$\mathrm{H}$

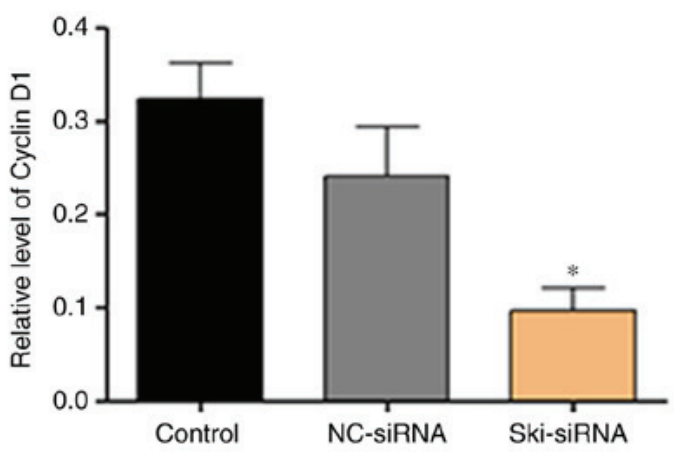

Figure 5. Protein expression of PCNA, CDK4 and cyclin D1 in OS cell lines following transfection with Ski-siRNA. (A) Western blot analysis revealed that the knockdown of Ski significantly decreased the PCNA, CDK4 and cyclin D1 protein levels in MG63 cells. (B-D) Statistical analysis of PCNA, CDK4 and cyclin D1 protein levels in MG63 cell following the knockdown of Ski at $48 \mathrm{~h}$. (E) Western blot analysis revealed that the knockdown of Ski significantly decreased PCNA, CDK4 and cyclin D1 protein levels in U2OS cells. (F-H) Statistical analysis of PCNA, CDK4 and cyclin D1 protein levels in U2OS cell following the knockdown of Ski at $48 \mathrm{~h}$. Values are expressed as the means $\pm \mathrm{SD}(\mathrm{n}=3) .{ }^{*} \mathrm{P}<0.05$ compared with control or NC-siRNA groups). OS, osteosarcoma.

following the knockdown of the Ski gene, as shown by wound healing assays. Therefore, the results revealed that Ski knockdown suppressed OS cell metastasis. In addition, MMPs are considered to play an essential role in collagen degradation, and can promote the migration and invasion of cancer cells $(32,33)$, thereby exerting a profound effect on tumor metastasis. In 
A

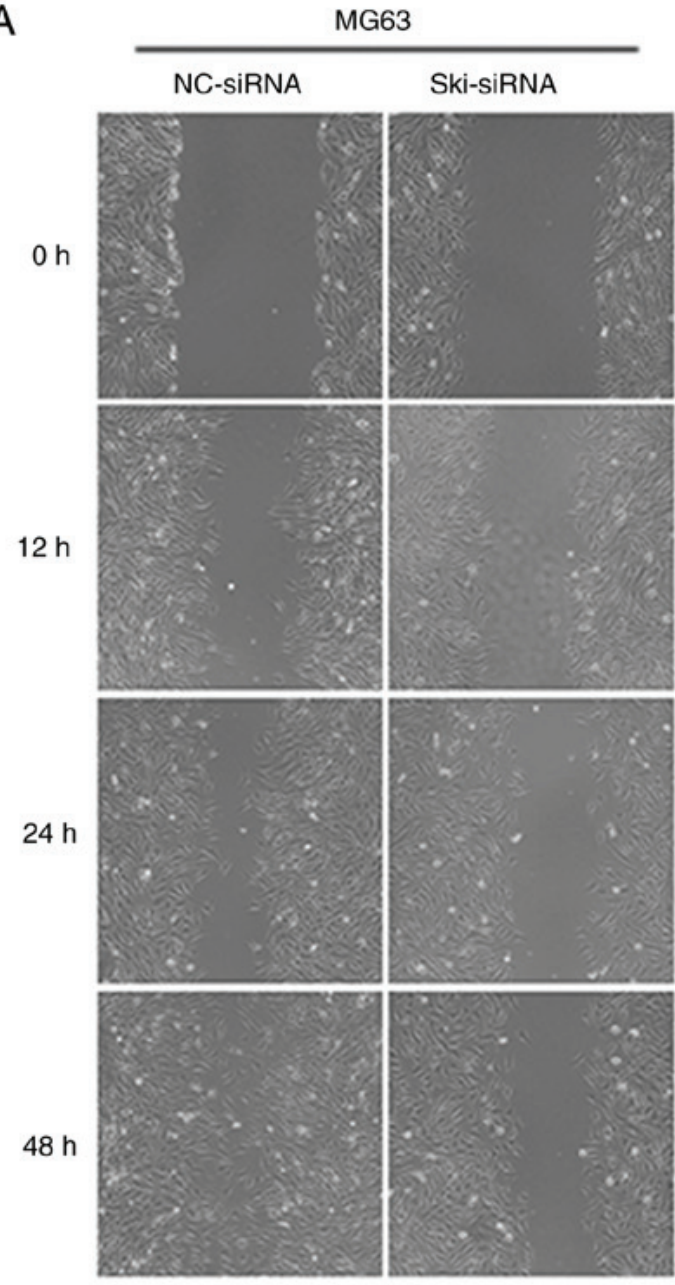

B

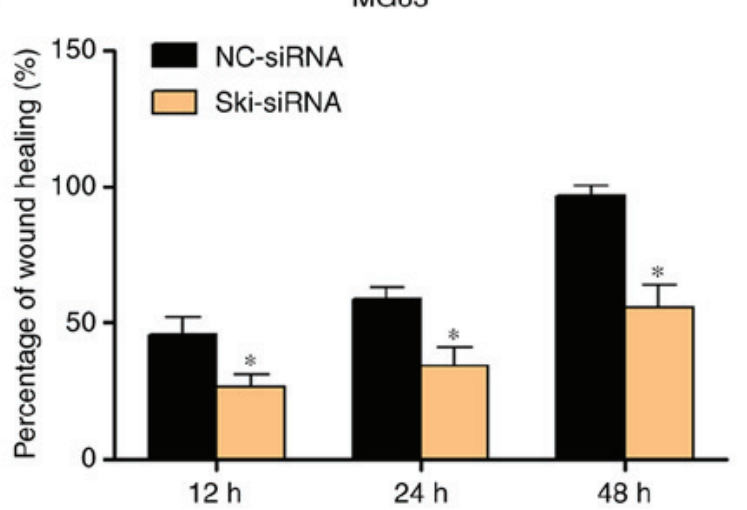

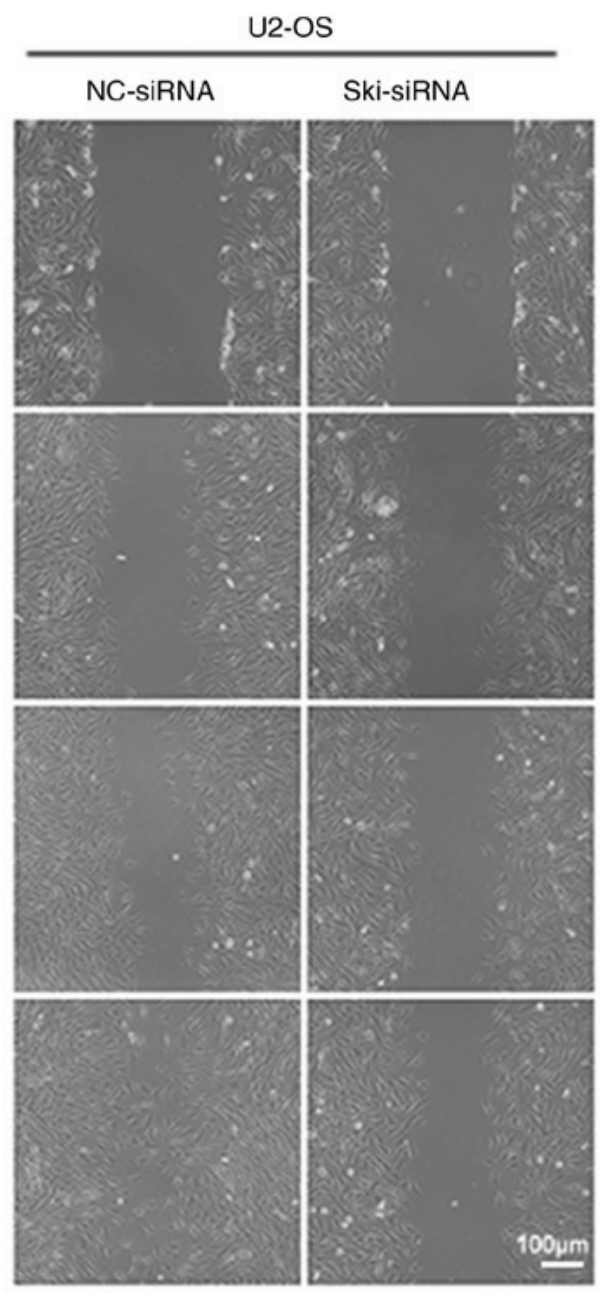

C

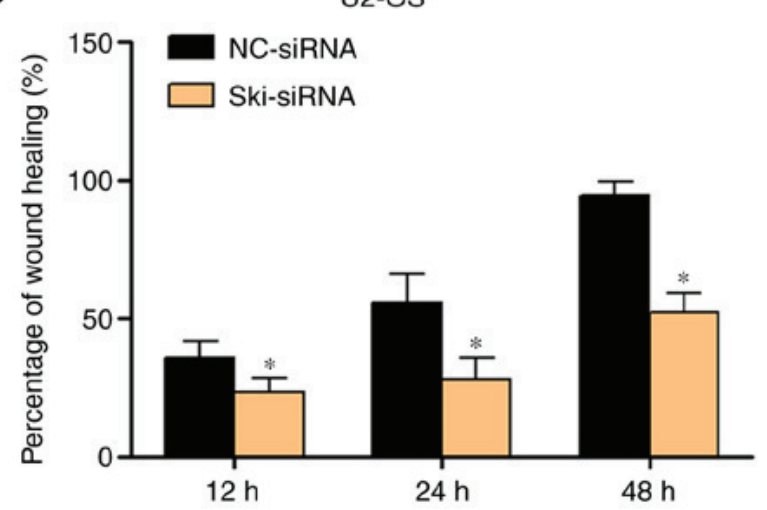

Figure 6. Knockdown of Ski decreased the migration of OS cells. (A) The wound healing assay revealed that the knockdown of Ski significantly decreased the migration of MG63 cells and U2OS cells. (B) Statistical analysis of the migration rate of MG63 cells. (C) Statistical analysis of migration rate of U2OS cells. Values are expressed as the means $\pm \mathrm{SD}(\mathrm{n}=3)$. ${ }^{*} \mathrm{P}<0.05$ compared with NC-siRNA groups). OS, osteosarcoma.

this study, it was found that MMP2 and MMP9 expression levels were significantly decreased following the knockdown of Ski. Qin et al reported that PAD1 promotes breast cancer cell metastasis by regulating the ERK1/2/MMP2 signaling pathway (34). Li et al found that the knockdown of TKTL1 decreased ESCC cell metastasis by downregulating MMP2 and MMP9 expression (35). Moreover, Arndt et al reported that Fussel-15, a new member of the Ski family, plays a vital role in fibroblast migration (36). In this study, it was found that the knockdown of the Ski gene markedly suppressed the migration in OS cells, and that the expression of MMP2 and MMP9 decreased significantly. The above-mentioned data demonstrated that Ski knockdown significantly decreased OS cell migration by suppressing MMP2 and MMP9 expression.

The PI3K/Akt pathway plays a critical regulatory role in tumorigenesis by regulating cell proliferation and metastasis $(37,38)$. There is evidence to indicate that the PI3K/Akt pathway is activated in the pathological process of OS $(39,40)$. The activation of Akt further phosphorylates multiple proteins that regulate cellular proliferation and migration (41). Therefore, 
A

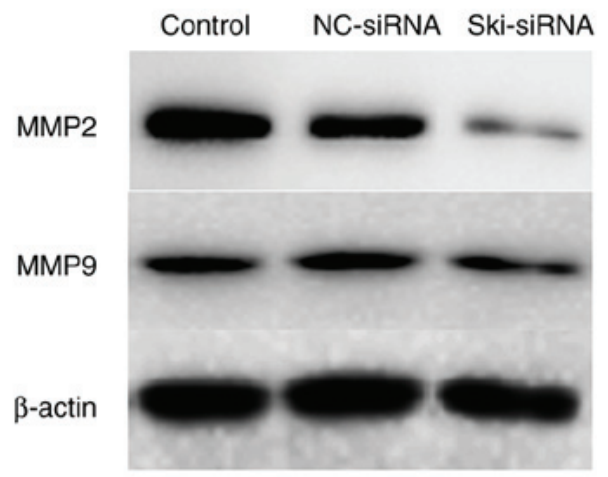

B

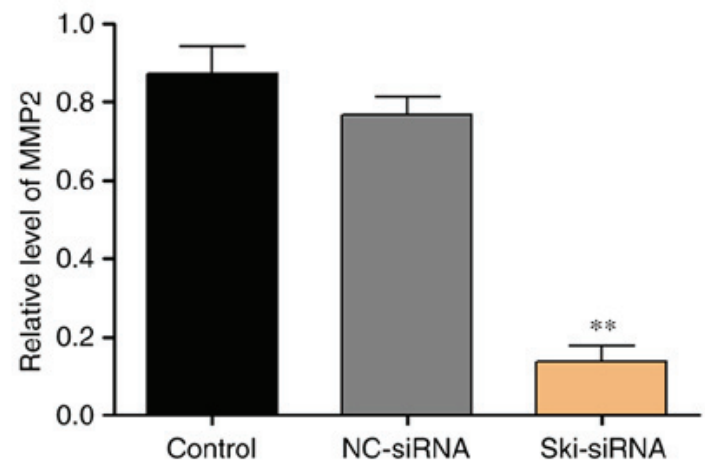

C

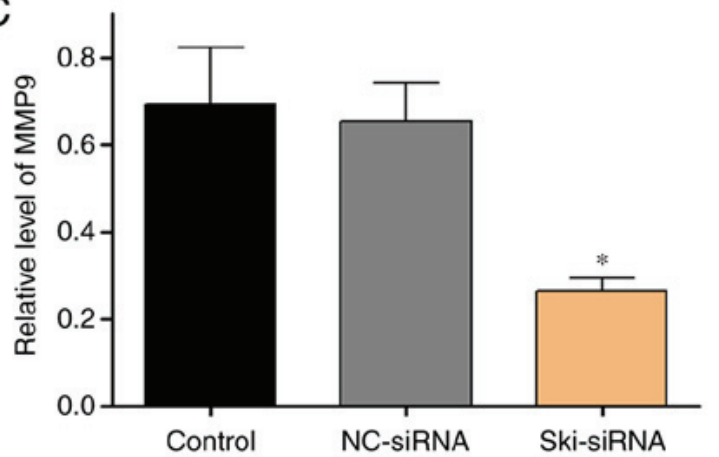

D

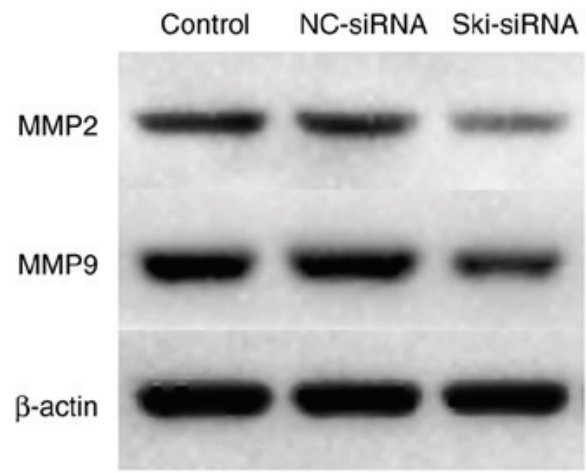

E

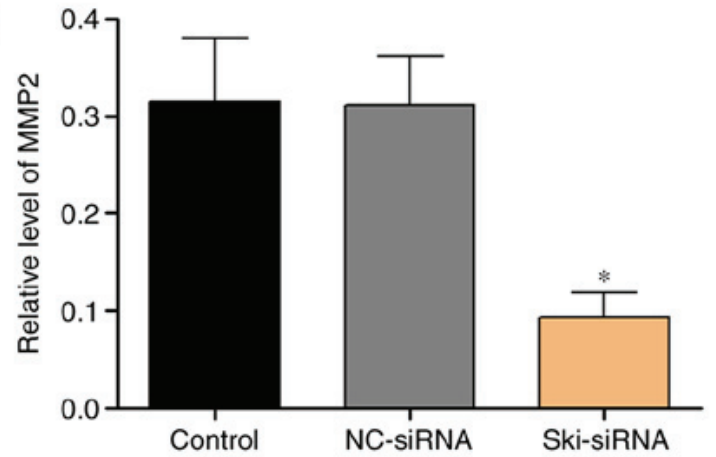

F

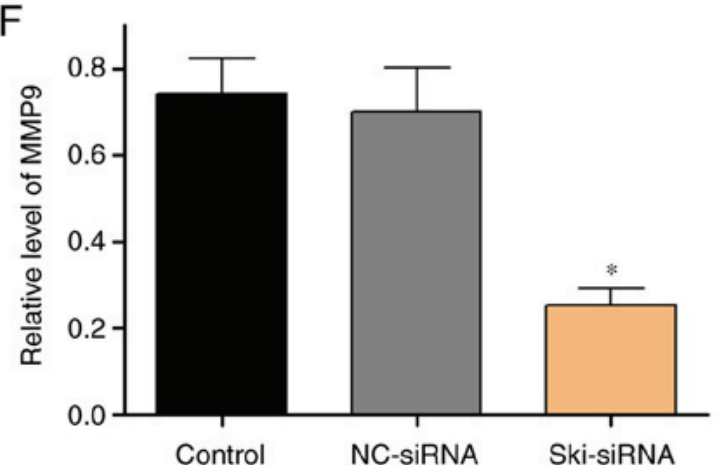

Figure 7. Protein expression of MMP2 and MMP9 in OS cell lines following transfection with Ski-siRNA. (A) Knockdown of Ski significantly decreased MMP2 and MMP9 protein levels in MG63 cells. (B and C) Statistical analysis of MMP2 and MMP9 expression in MG63 cells following the knockdown of Ski at $48 \mathrm{~h}$. Values are expressed as the means $\pm \mathrm{SD}(\mathrm{n}=3)$. ${ }^{*} \mathrm{P}<0.05$, vs. the control or NC-siRNA group). (D) Knockdown of Ski significantly decreased MMP2 and MMP9 protein levels in U2OS cells. (E and F) Statistical analysis of MMP2 and MMP9 expression in U2OS cells following the knockdown of Ski at $48 \mathrm{~h}$. Values are expressed as the means $\pm \mathrm{SD}(\mathrm{n}=3)$. ${ }^{*} \mathrm{P}<0.05$, vs. the control or NC-siRNA group). OS, osteosarcoma.

inhibiting the phosphorylation of the PI3K/Akt pathway represents a potential treatment method for OS $(42,43)$. Thus, inhibiting the phosphorylation of the PI3K/Akt pathway, by various means, disrupts OS progression. It has been reported that the PI3K-specific inhibitor, LY294002, markedly suppresses OS cell proliferation and migration by downregulating the activity of the PI3K/Akt pathway (44-46). Jiang et al found that the knockdown of the DDX46 gene inhibited the tumorigenesis of OS cells by suppressing the phosphorylation of the PI3K/Akt signaling pathway (47). Chen et al found that isoliquiritigenin suppressed OS cell proliferation by downregulating the PI3K/Akt pathway (48). Similarly, it has been revealed that TROP promotes OS cell proliferation and migration by activating the PI3K/Akt signaling pathway (40). Of note, a previous study demonstrated that there may be a potential connection between Ski and the PI3K/Akt signaling pathway; for example, Ski can be phosphorylated by Akt and this phosphorylation is elevated by the activation of the PI3K/Akt pathway (49). However, whether the roles of Ski in OS cells are regulated by the PI3K/Akt pathway remain unclear.

In the present study, the underlying mechanisms of the biological functions of Ski, including the proliferation and migration of OS cell lines were investigated. It was found that Ski knockdown significantly inhibited the phosphorylation levels of both PI3K and Akt in OS cell lines. In order to confirm the association between Ski and the PI3K/Akt signaling pathway in OS cell lines, an inhibitor of PI3K (LY 294002) was used. In this study, it was found that LY 294002 significantly enhanced the inhibitory effects of Ski-siRNA on MG63 cell proliferation and migration, and similar results were obtained with the U2OS cells. The above-mentioned results strongly demonstrated that Ski knockdown notably inhibited OS proliferation and migration by blocking the PI3K/Akt signaling pathway. To further confirm the function of Ski in 


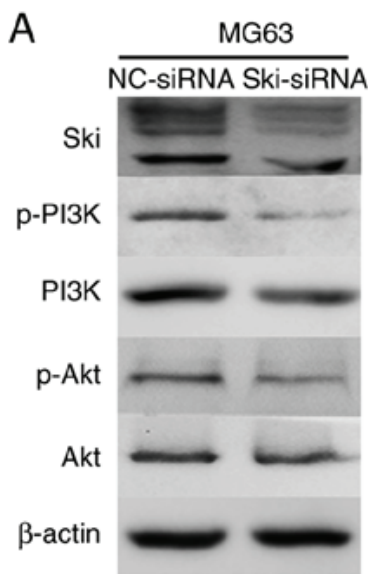

C
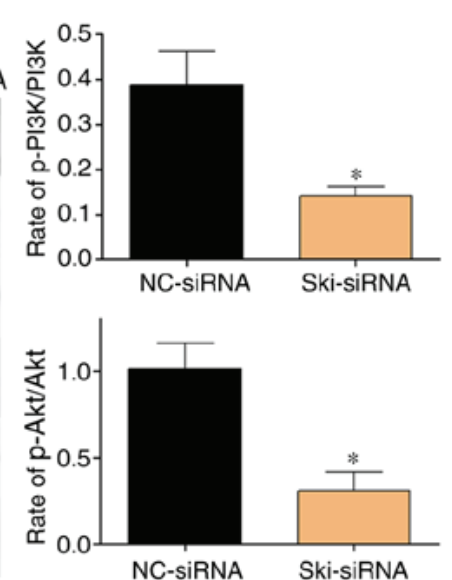

MG63

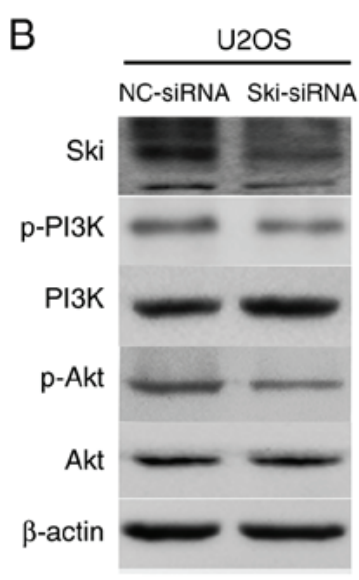

D

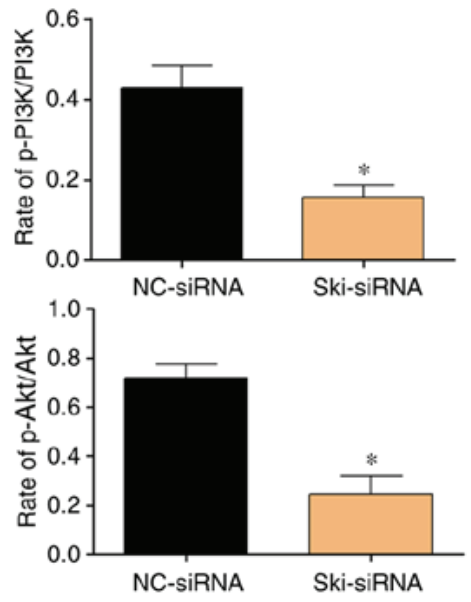

U2OS
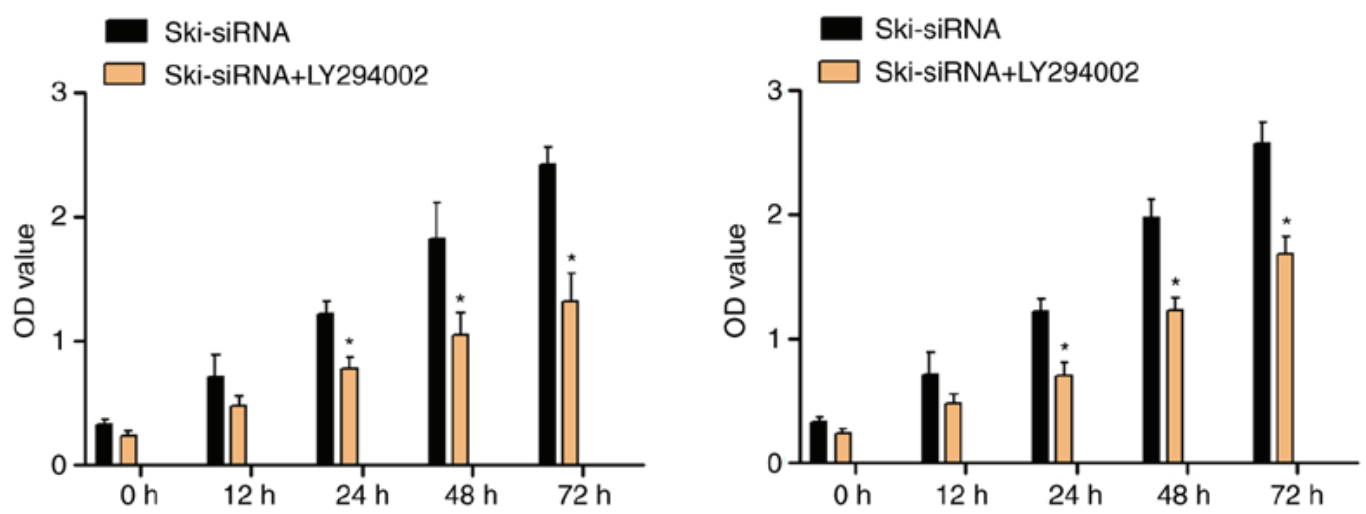

$E$

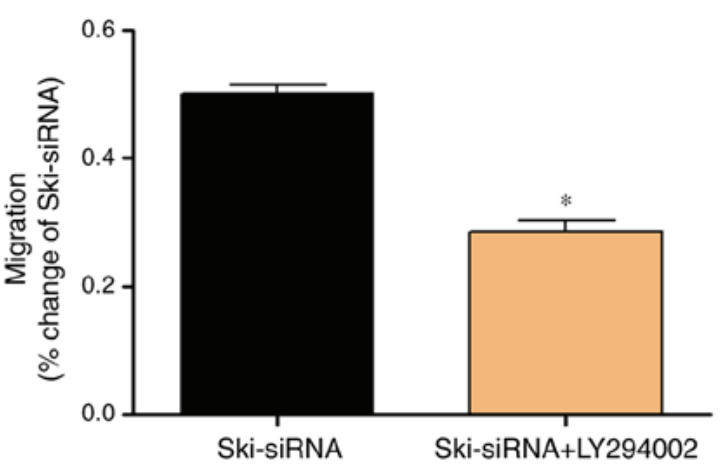

$\mathrm{F}$

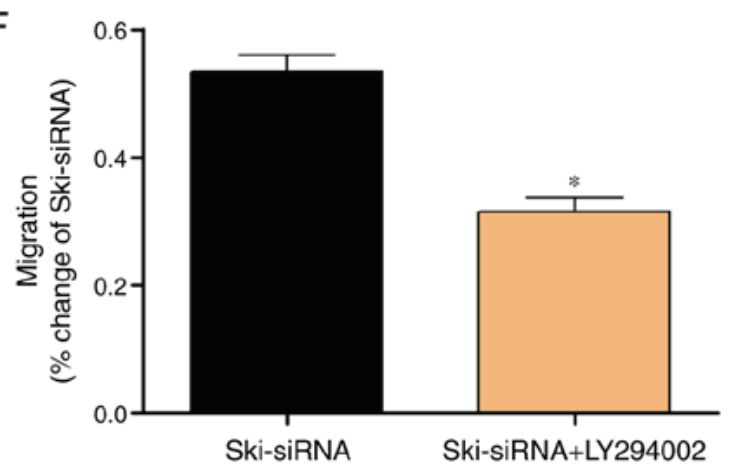

Figure 8. Knockdown of Ski reduces the levels of p-PI3K and p-Akt in OS cell lines, and the effect of Ski-siRNA in the presence or absence of the LY294002 on OS cells proliferation and migration. (A) Knockdown of Ski significantly decreased p-PI3K and p-Akt protein levels in MG63 cells. (B) Knockdown of Ski significantly decreased p-PI3K and p-Akt protein levels in U2OS cells. Values are expressed as the mean $\pm \mathrm{SD}\left(\mathrm{n}=3\right.$ ). ${ }^{*} \mathrm{P}<0.05$, vs. the NC-siRNA group). (C and D) Proliferation of MG63 and U2OS cells examined by CCK8 assay; LY294002 markedly enhanced the inhibitory effects of Ski-siRNA on OS cell proliferation. (E and F) Statistical analysis the effect of LY294002 on the migration rate of OS cells following transfectiong with Ski-siRNA. Values are expressed as the means $\pm \mathrm{SD}(\mathrm{n}=3) .{ }^{*} \mathrm{P}<0.05$, vs. the Ski-siRNA group).

OS, further studies on cell proliferation and migration trends following Ski gene transfection are warranted and our team aims to continue to study its role in OS cells.

In conclusion, this study demonstrates for the first time, to the best of our knowledge, that the expression of Ski was markedly increased in OS tissues and cell lines, and that Ski knockdown decreased OS cell proliferation and migration, which was performed by blocking the PI3K/Akt signaling pathway. It can thus be concluded that Ski may become a potential therapeutic target molecule in the treatment of OS.

\section{Acknowledgements}

The authors would like to thank the Research Core Facility of West China Hospital of Sichuan University for providing support with the experimental techniques.

\section{Funding}

This study was supported by The National Natural Science Foundation of China (grant no. 81672165) and the Science 
And Technology Program of Sichuan Province (grant no. 2019YFS0123).

\section{Availability of data and materials}

The datasets used and analyzed in the present study are available from the corresponding author on reasonable request.

\section{Authors' contributions}

$\mathrm{XZ}$ and YF were involved in the design of the study, performed the experiments and drafted the manuscript. XW performed the experiments. ZY and DL designed and analyzed the immunohistochemistry data. PK and MT were involved in the design of the study, and in the critical appraisal of the manuscript. All authors have read and approved the final version of the manuscript to be published.

\section{Ethics approval and consent to participate}

The present study was approved by the Ethics Committee of West China Hospital of Sichuan University (Chengdu, China). Written informed consent was obtained from all patients.

\section{Patient consent for publication}

Not applicable.

\section{Competing interests}

The authors declare that they have no competing interests.

\section{References}

1. Lei Z, Duan H, Zhao T, Zhang Y, Li G, Meng J, Zhang S and Yan W: PARK2 inhibits osteosarcoma cell growth through the JAK2/STAT3/VEGF signaling pathway. Cell Death Dis 9: 375, 2018.

2. Morrow JJ and Khanna C: Osteosarcoma genetics and epigenetics: Emerging biology and candidate therapies. Crit Rev Oncog 20: 173-197, 2015.

3. Na KY, Bacchini P, Bertoni F, Kim YW and Park YK: Syndecan-4 and fibronectin in osteosarcoma. Pathology 44: 325-330, 2012.

4. Lilic V, Lilic G, Filipovic S, Milosevic J, Tasic M and Stojiljkovic M: Modern treatment of invasive carcinoma of the uterine cervix. J BUON 14: 587-592, 2009.

5. Carnelio S, Pai K, Rao N, Solomon M and Ahasan A: Metastatic osteosarcoma to the maxilla: A case report and a review of the literature. Quintessence Int 33: 397-399, 2002.

6. Bonnon C and Atanasoski S: c-Ski in health and disease. Cell Tissue Res 347: 51-64, 2012.

7. Li Y, Turck CM, Teumer JK and Stavnezer E: Unique sequence, ski, in sloan-kettering avian retroviruses with properties of a new cell-derived oncogene. J Virol 57: 1065-1072, 1986.

8. Luo K, Stroschein SL, Wang W, Chen D, Martens E, Zhou S and Zhou Q: The Ski oncoprotein interacts with the Smad proteins to repress TGFbeta signaling. Genes Dev 13: 2196-2206, 1999.

9. Villanacci V, Bellone G, Battaglia E, Rossi E, Carbone A, Prati A Verna C, Niola P, Morelli A, Grassini M and Bassotti G: Ski/SnoN expression in the sequence metaplasia-dysplasia-adenocarcinoma of Barrett's esophagus. Hum Pathol 39: 403-409, 2008.

10. Buess M, Terracciano L, Reuter J, Ballabeni P, Boulay JL, Laffer U, Metzger U, Herrmann R and Rochlitz C: Amplification of SKI is a prognostic marker in early colorectal cancer. Neoplasia 6 : 207-212, 2004.

11. Nakao T, Kurita N, Komatsu M, Yoshikawa K, Iwata T, Utsunomiya T and Shimada M: Expression of thrombospondin-1 and Ski are prognostic factors in advanced gastric cancer. Int $\mathrm{J}$ Clin Oncol 16: 145-152, 2011.
12. Heider TR, Lyman S, Schoonhoven R and Behrns KE: Ski promotes tumor growth through abrogation of transforming growth factor-beta signaling in pancreatic cancer. Ann Surg 246: 61-68, 2007.

13. Chen D, Lin Q, Box N, Roop D, Ishii S, Matsuzaki K, Fan T, Hornyak TJ, Reed JA, Stavnezer E, et al: SKI knockdown inhibits human melanoma tumor growth in vivo. Pigment Cell Melanoma Res 22: 761-772, 2009.

14. Fumagalli S, Doneda L, Nomura N and Larizza L: Expression of the c-ski proto-oncogene in human melanoma cell lines. Melanoma Res 3: 23-27, 1993.

15. Zhao X, Zhou KS, Li ZH, Nan W, Wang J, Xia YY and Zhang HH: Knockdown of Ski decreased the reactive astrocytes proliferation in vitro induced by oxygen-glucose deprivation/reoxygenation. J Cell Biochem 119: 4548-4558, 2018.

16. Zhao X, Wang XW, Zhou KS, Nan W, Guo YQ, Kou JL, Wang J, $\mathrm{Xia}$ YY and Zhang HH: Expression of Ski and its role in astrocyte proliferation and migration. Neuroscience 362: 1-12, 2017.

17. Wang Z, Sun X, Bao Y, Mo J, Du H, Hu J and Zhang X: E2F1 silencing inhibits migration and invasion of osteosarcoma cells via regulating DDR1 expression. Int J Oncol 51: 1639-1650, 2017.

18. Jiang W, Yu Y, Liu J, Zhao Q, Wang J, Zhang J and Dang X: Downregulation of Cdc6 inhibits tumorigenesis of osteosarcoma in vivo and in vitro. Biomed Pharmacother 115: 108949, 2019.

19. Chen R, Huang LH, Gao YY, Yang JZ and Wang Y: Identification of differentially expressed genes in MG63 osteosarcoma cells with drug-resistance by microarray analysis. Mol Med Rep 19: 1571-1580, 2019.

20. Chen R, Wang G,Zheng Y,Hua Y and CaiZ: Drug resistance-related microRNAs in osteosarcoma: Translating basic evidence into therapeutic strategies. J Cell Mol Med 23: 2280-2292, 2019.

21. Kokura K, Kim H, Shinagawa T, Khan MM, Nomura T and Ishii S: The Ski-binding protein C184M negatively regulates tumor growth factor-beta signaling by sequestering the Smad proteins in the cytoplasm. J Biol Chem 278: 20133-20139, 2003.

22. Li J, Li P, Zhang Y, Li GB, Zhou YG, Yang K and Dai SS: c-Ski inhibits the proliferation of vascular smooth muscle cells via suppressing Smad3 signaling but stimulating p38 pathway. Cell Signal 25: 159-167, 2013.

23. Li J, Zhao L, He X, Yang T and Yang K: MiR-21 inhibits c-Ski signaling to promote the proliferation of rat vascular smooth muscle cells. Cell Signal 26: 724-729, 2014.

24. Colmenares $C$ and Stavnezer E: The ski oncogene induces muscle differentiation in quail embryo cells. Cell 59: 293-303, 1989.

25. Zhang $\mathrm{H}$ and Stavnezer E: Ski regulates muscle terminal differentiation by transcriptional activation of Myog in a complex with Six1 and Eya3. J Biol Chem 284: 2867-2879, 2009.

26. Macias-Silva M, Li W, Leu JI, Crissey MA and Taub R: Up-regulated transcriptional repressors SnoN and Ski bind Smad proteins to antagonize transforming growth factor-beta signals during liver regeneration. J Biol Chem 277: 28483-28490, 2002.

27. Wang L, Hou Y, Sun Y, Zhao L, Tang X, Hu P, Yang J, Zeng Z, Yang G, Cui X and Liu M: c-Ski activates cancer-associated fibroblasts to regulate breast cancer cell invasion. Mol Oncol 7: 1116-1128, 2013.

28. Reed JA, Lin Q, Chen D, Mian IS and Medrano EE: SKI pathways inducing progression of human melanoma. Cancer Metastasis Rev 24: 265-272, 2005.

29. Wang P, Chen Z, Meng ZQ, Fan J, Luo JM, Liang W, Lin JH, Zhou ZH, Chen H, Wang K, et al: Dual role of Ski in pancreatic cancer cells: Tumor-promoting versus metastasis-suppressive function. Carcinogenesis 30: 1497-1506, 2009.

30. Atanasoski S, Notterpek L, Lee HY, Castagner F, Young P, Ehrengruber MU, Meijer D, Sommer L, Stavnezer E, Colmenares C and Suter U: The protooncogene Ski controls schwann cell proliferation and myelination. Neuron 43: 499-511, 2004.

31. Huang J, Dey R, Wang Y, Jakoncic J, Kurinov I and Huang XY: Structural insights into the induced-fit inhibition of fascin by a small-molecule inhibitor. J Mol Biol 430: 1324-1335, 2018.

32. Cao LL, Pei XF, Qiao X, Yu J, Ye H, Xi CL, Wang PY and Gong ZL: SERPINA3 silencing inhibits the migration, invasion, and liver metastasis of colon cancer cells. Dig Dis Sci 63: 2309-2319, 2018.

33. de Oliveira Poswar F, de Carvalho Fraga CA, Gomes ES, Farias LC, Souza LW, Santos SH, Gomez RS, de-Paula AM and Guimarães AL: Protein expression of MMP-2 and MT1-MMP in actinic keratosis, squamous cell carcinoma of the skin, and basal cell carcinoma. Int J Surg Pathol 23: 20-25, 2015. 
34. Qin H, Liu X, Li F, Miao L, Li T, Xu B, An X, Muth A, Thompson PR, Coonrod SA and Zhang X: PAD1 promotes epithelial-mesenchymal transition and metastasis in triple-negative breast cancer cells by regulating MEK1-ERK1/2-MMP2 signaling. Cancer Lett 409: 30-41, 2017.

35. Li J, Zhu SC, Li SG, Zhao Y, Xu JR and Song CY: TKTL1 promotes cell proliferation and metastasis in esophageal squamous cell carcinoma. Biomed Pharmacother 74: 71-76, 2015.

36. Arndt S, Schmidt J, Wacker E, Karrer S and Bosserhoff AK: Fussel-15, a new player in wound healing, is deregulated in keloid and localized scleroderma. Am J Pathol 178: 2622-2631, 2011.

37. Brader S and Eccles SA: Phosphoinositide 3-kinase signalling pathways in tumor progression, invasion and angiogenesis. Tumori 90: 2-8, 2004.

38. Zhang J, Yu XH, Yan YG, Wang $\mathrm{C}$ and Wang WJ: PI3K/Akt signaling in osteosarcoma. Clin Chim Acta 444: 182-192, 2015.

39. Cohen-Solal KA, Boregowda RK and Lasfar A: RUNX2 and the $\mathrm{PI} 3 \mathrm{~K} / \mathrm{AKT}$ axis reciprocal activation as a driving force for tumor progression. Mol Cancer 14: 137, 2015.

40. Gu QZ, Nijiati A, Gao X, Tao KL, Li CD, Fan XP and Tian Z: TROP2 promotes cell proliferation and migration in osteosarcoma through PI3K/AKT signaling. Mol Med Rep 18: 1782-1788, 2018.

41. Zhang Y, Cheng H, Li W, Wu H and Yang Y: Highly-expressed $\mathrm{P} 2 \mathrm{X} 7$ receptor promotes growth and metastasis of human HOS/MNNG osteosarcoma cells via PI3K/Akt/GSK3// $\beta$-catenin and $\mathrm{mTOR} / \mathrm{HIF} 1 \alpha /$ VEGF signaling. Int J Cancer 145: 1068-1082, 2019.

42. Ma J, Huang H, Han Z, Zhu C and Yue B: RLN2 is a positive regulator of Akt-2-induced gene expression required for osteosarcoma cells invasion and chemoresistance. Biomed Res Int 2015: 147468,2015
43. Wang H, Luo QF, Peng AF, Long XH, Wang TF, Liu ZL, Zhang GM, Zhou RP, Gao S, Zhou Y and Chen WZ: Positive feedback regulation between Akt phosphorylation and fatty acid synthase expression in osteosarcoma. Int J Mol Med 33: 633-639, 2014.

44. Liu T, Zhou W, Cai B, Chu J, Shi G, Teng H, Xu J, Xiao J and Wang Y: IRX2-mediated upregulation of MMP-9 and VEGF in a PI3K/AKT-dependent manner. Mol Med Rep 12: 4346-4351, 2015.

45. Long XH, Zhong ZH, Peng AF, Zhu LB, Wang H, Zhang GM and Liu ZL: LY294002 suppresses the malignant phenotype and sensitizes osteosarcoma cells to pirarubicin chemotherapy. Mol Med Rep 10: 2967-2972, 2014.

46. Zhou Y, Zhu LB, Peng AF, Wang TF, Long XH, Gao S, Zhou RP and Liu ZL: LY294002 inhibits the malignant phenotype of osteosarcoma cells by modulating the phosphatidylinositol 3-kinase/Akt/fatty acid synthase signaling pathway in vitro. Mol Med Rep 11: 1352-1357, 2015.

47. Jiang F, Zhang D, Li G and Wang X: Knockdown of DDX46 inhibits the invasion and tumorigenesis in osteosarcoma cells. Oncol Res 25: 417-425, 2017.

48. Chen J, Liu C, Yang QQ, Ma RB, Ke Y, Dong F and Wu XE: Isoliquiritigenin suppresses osteosarcoma U2OS cell proliferation and invasion by regulating the PI3K/Akt signalling pathway. Chemotherapy 63: 155-161, 2018

49. Band AM, Björklund $M$ and Laiho $M$ : The phosphatidylinositol 3-kinase/Akt pathway regulates transforming growth factor- $\{$ beta\} signaling by destabilizing ski and inducing Smad7. J Biol Chem 284: 35441-35449, 2009. 